\title{
Eosinophils in the 1990s: New perspectives on their role in health and disease
}

\author{
A.J. Wardlaw \\ Department of Respiratory Medicine, Leicester University Medical School, Glenfield Hospital, Groby \\ Road, Leicester LE3 9QP, UK
}

\section{Introduction}

Eosinophils have traditionally been somewhat neglected over the years by clinicians and pathologists alike, being seen as a sort of poor man's neutrophil, appearing in a supportive role as part of 'acute inflammation' with an occasional lead part in exotic diseases such as Churg-Strauss syndrome or hypereosinophilic syndrome. This neglect is unwarranted, both because the eosinophil is one of the most striking of cells, readily identified in haematoxylin and eosin (H\&E) stained sections with their bilobed nuclei and bright red granules, and because the eosinophil is closely associated with two of the most common and universal of diseases, asthma and parasitic infection. The characteristic appearance of the eosinophil resulted in its early identification by Ehrlich in 1879 and its association with asthma and allergic disease was soon recognized. ${ }^{1}$ Curiosity about its role in asthma and other diseases has persisted ever since. In recent years there has been an explosion of interest in the eosinophil reflected in an exponential increase in the number of published papers and books devoted to the cell. ${ }^{2-5}$ This interest has been mainly the result of increasing evidence that the eosinophil may be responsible for much of the tissue damage seen in asthma and the hope that modulation of eosinophil function may be an effective therapy for the disease. The purpose of this paper is firstly to review recent findings about the biology of the eosinophil, emphasizing the features that are distinctive about the eosinophil compared to other leucocytes and especially neutrophils. Secondly, I will briefly summarize the possible role of the eosinophil in the diseases with which it is associated.

\section{Morphology and ultrastructure}

Eosinophils are non-dividing, bone marrowderived, granule-containing cells. They are approx-

Correspondence: A.J. Wardlaw, F.R.C.P., Ph.D. Received: 7 January 1994 imately $8 \mu \mathrm{m}$ in diameter. One of their most $\partial$ characteristic features are the membrane-bound specific granules of which there are about 20 per $O$ human eosinophil. These are spherical or ovoid, $\mathcal{E}$ and contain a crystalline core surrounded by a less electron-dense matrix. ${ }^{6}$ The core is comprised of $\frac{}{2}$ major basic protein (MBP) and the matrix contains $\vec{\longrightarrow}$ the other three basic granule proteins, eosinophil cationic protein (ECP), eosinophil peroxidase $\frac{C}{6}$ (EPO) and eosinophil-derived neurotoxin (EDN or ${ }^{\circ}$ EPX). ${ }^{7}$ These basic proteins stain avidly with dyeg $\vec{\ominus}$ such as eosin from which the cell gained its namE. Eosinophils also contain lipid bodies which xe non-membrane-bound organelles and the principâl store of arachidonic acid esterified into glycero- $\frac{}{0}$ phospholipids. ${ }^{8}$ Eosinophil primary granules are a third type of intracellular organelle which contain $\stackrel{\varnothing}{\Phi}$ Charcot-Leyden crystal (CLC) protein. CLC pro- $\stackrel{2}{\overrightarrow{7}}$ tein is also found diffusely in the nucleus and $\frac{O}{3}$ cytoplasm in activated eosinophils. Primary granules are recognized by the absence of a core and are of variable size, being often larger than the specific granules. They make up approximately $5 \% \frac{3}{3}$ of eosinophil granules. ${ }^{9}$ Tissue eosinophils also contain a number of small granules which stain 3 . intensely for acid phosphatase and aryl sul- $\delta$ phatase. $^{10,11}$

\section{Eosinophil production}

Eosinophils like other leucocytes differentiate from stem cell precursors in the bone marrow. They then of migrate into the peripheral blood where they ${ }^{N}$ circulate with a half life of about 18 hours before $\underset{\omega}{N}$ migrating into tissue. Eosinophils are primarily tissue-dwelling cells with about one blood 0

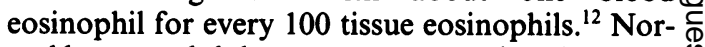
mal human adult bone marrow contains about $3 \% \stackrel{f}{?}$ eosinophils of which a third are mature and 0 two-thirds are myelocytic precursors. Eosinophilic $\stackrel{\vec{O}}{\mathrm{O}}$ myelocytes are large cells with a single-lobed $\stackrel{\oplus}{\oplus}$ nucleus, expanded Golgi and extensive dilated $\stackrel{\odot}{\odot}$ cisterns of rough endoplasmic reticulum. They $\underset{-}{0}$ 
become identifiable when they develop the core containing specific granules which initially are interspersed with large numbers of homogenous dense granules. ${ }^{13}$

There is now substantial evidence that the massive increase in eosinophils associated with helminthic parasitic infection is T-cell dependent..$^{14,15}$ Three T-cell-derived cytokines have been shown to promote eosinophil growth and differentiation, interleukin-3 (IL-3), IL-5 and granulocyte-macrophage colony-stimulating factor (GM-CSF). Eosinophil and basophil colonies appear together in colony-forming assays. ${ }^{16}$ Mouse IL-5, but not human IL-5, is a growth factor for B cells. IL-5 is a disulphide-linked homodimeric glycoprotein with a molecular weight of $40-45 \mathrm{kDa} \cdot{ }^{17,18}$ The dimers are aligned in a head to tail fashion and dimerization is essential for function. ${ }^{19}$ Culture of mouse bone marrow suggested that IL-5 was a late differentiation factor and could not support eosinophil growth from early precursors. These steps appeared to require other cytokines such as IL-3 and GM-CSF. ${ }^{20}$ However, IL-5 transgenic mice had a marked peripheral blood and tissue eosinophilia with increased numbers of eosinophil precursors in their bone marrow. ${ }^{21,22}$ Despite a marked eosinophilia these mice had no obvious pathological defect. The observation that IL-5 alone was sufficient to generate an eosinophilia is consistent with the fact that increases in numbers of eosinophils are often seen without expansion of the other myeloid lineages. Both IL-3 and GM-CSF induce eosinophil production in vitro in human cord blood culture ${ }^{23}$ and after in vivo administration, although the increase in the number of eosinophils was modest compared to other lineages. ${ }^{24}$ In humans the genes for IL-3, IL-4, IL-5 and GM-CSF are clustered on the long arm of chromosome $5 .{ }^{25}$ The receptors for IL-3, IL-5 and GM-CSF are structurally similar. ${ }^{26}$ They consist of unique though homologous $\alpha$ chains, which bind with low affinity to their respective cytokines with a $K_{d}$ in the region of $10 \mathrm{nmol} / 1$. There is a common $\beta$ chain which is non-covalently associated with the $\alpha$ chains at the cell surface and transforms the receptor into one of high affinity $\left(K_{d} 150\right.$ picomoles $(\mathrm{pm}))$. The $\beta$ chain is required for signal transduction. Unlike the $\alpha$ chains of IL-3 and GM-CSF, the $\alpha$ chain of the IL-5R can bind IL-5 with relatively high affinity $\left(K_{\mathrm{d}} 250-590 \mathrm{pm}\right) \mathrm{.}^{27,28}$

In many conditions associated with increases in eosinophils, including asthma, ${ }^{29}$ parasitic disease, ${ }^{30}$ IL-2 therapy, ${ }^{31}$ hypereosinophilic syndrome $(\text { HES })^{32}$ and eosinophilia/myalgia syndrome, ${ }^{33}$ evidence of increased IL-5 production has been obtained. IL-5 messenger RNA (mRNA) has been detected in eosinophilic Hodgkins disease. ${ }^{34}$ Antibodies against IL-5 abolishes the eosinophilia in parasitized animals. ${ }^{35}$ Although IL-5 has been detected in mast cells and eosinophils, ${ }^{36}$ it is likely that T-lymphocytes are the principal source of this cytokine. $T$ cells, as well as being divided into subsets on the basis of their receptor phenotype, can be distinguished by their cytokine profile. T-helper type 1 (Th1) cells produce IL-2 and interferon- $\gamma$ (IFN- $\gamma$ ), Th2 cells IL-4 and IL-5, whereas GM-CSF and IL-3 are elaborated by both cell types. ${ }^{37}$ T-cells with a $\mathrm{Th} 2$ profile of cytokine production are found in allergic and eosinophilic parasitic disease. Eosinophilia in many diseases therefore appears to be due to a specific type of $T$-cell response to certain types of antigen. For example, allergens in allergic disease and parasitic antigens in helminthic infections. Drug-induced eosinophilia may be due to the drug acting as a hapten for a $\mathrm{Th} 2$ response.

\section{Eosinophil heterogeneity}

Peripheral blood eosinophils from normal individuals are relatively dense cells which separate out from other leucocytes in the lower bands of Percoll or Metrizamide discontinuous density gradients. For many years these differences were the basis for the standard method of purifying eosinophils. This has now been largely superseded by immunomagnetic selection based on differences in expression of the low-affinity (immunoglobulin receptor. (Fc) $\gamma$ RIII, cluster of differentiation (CD)16) IgG receptor by eosinophils and neutrophils. ${ }^{38} \mathrm{~A}$ proportion of eosinophils from individuals with a raised eosinophil count are less dense than eosinophils from normal subjects. ${ }^{39}$ The mechanism for this heterogeneity is unclear. Hypodense eosinophils appear to be vacuolated and contain smaller-sized granules, although of equal numbers to normal density eosinophils. ${ }^{40}$ It is generally considered that hypodense eosinophils represent an activated phenotype. ${ }^{41}$ Thus hypodense eosinophils have increased oxygen consumption, ${ }^{42}$ increased cytotoxicity towards helminths $s^{43}$ and increased leukotrine C4 (LTC4) production. ${ }^{44}$ They release less platelet-activating factor (PAF) after stimulation with IgG sepharose beads but this appears to be the result of increased acetyl hydrolase activity. ${ }^{45}$ Stimulation of eosinophils either in the short term with PAF or in long-term culture with cytokines results in a hypodense phenotype and enhanced effector function. ${ }^{46}$ In contrast, hypodense eosinophils have a similar profile of leucocyte integrin and $\mathrm{Fc} y$ receptor expression to normal density cells ${ }^{47}$ and normal density cells from individuals with an eosinophilia are also primed. Nonetheless, the weight of evidence suggests that hypodensity represents a primed or partially activated phenotype. 


\section{Eosinophil receptors}

Like all leucocytes, eosinophils express various membrane receptors through which they communicate with the extracellular environment. These include adhesion receptors, Fc receptors and receptors for the recognition of soluble mediators (Figure 1).

\section{Adhesion receptors}

A critical aspect of leucocyte function is migration from the vascular space into extracellular tissue. The initial step in this process is adherence to postcapillary venular endothelium. This is mediated by binding of adhesion receptors on the surface of leucocytes to their ligands or counterstructures on endothelium. Adhesion receptors are grouped into several gene superfamilies, and include the integrin superfamily, members of the immunoglobulin superfamily, and the selectins. ${ }^{48,49}$ Integrins bind to members of the immunoglobulin receptor family and selectins bind, via their lectin domain, to carbohydrate counterstructures that include the moiety sialyl Lewis $\mathrm{X} .{ }^{50}$ Transmigration through vascular endothelium is a staged process in which the leucocyte is first tethered to the endothelial cell by binding of a selectin receptor to its carbohydrate ligand. The binding affinity of this interaction is relatively weak and the leucocyte rolls along the surface of the endothelium until it comes into contact with a priming stimulus such as a chemotactic mediator. This allows the leucocyte integrin receptor to bind to its corresponding immunoglobulin-like ligand. The resultant bond is much firmer than the selectin carbohydrate bond and results in the leucocyte flattening and transmigrating between endothelial cells. ${ }^{51}$ Three events are therefore required for migration to occur: (1) engagement of a selectin and its receptor; (2) leucocyte activation; and (3) engagement of the intergrin/immunoglobulin receptor bond. Having transmigrated through the endothelium, the leucocyte interacts with the extracellular matrix proteins through its integrin and other adhesion $\vec{\theta}$ receptors. Adhesion receptors and their ligands 3 potentially involved in eosinophil function are summarized in Table I. As with neutrophils, Lselectin is shed when eosinophils are stimulated and ${ }^{\circ}$ BAL eosinophils that have migrated into the 0 airways express very little L-selectin. ${ }^{52}$

One potential mechanism for preferential 옥 localization of eosinophils (as opposed to neut- $\overrightarrow{ }$ rophils) at inflammatory foci is a selective adhesion pathway. IL-5 and IL-3 increase eosinophil, but not neutrophil, adhesion to unstimulated human umbilical vein endothelial cells (HUVEC). Eosinophils but not neutrophils can utilize the ver

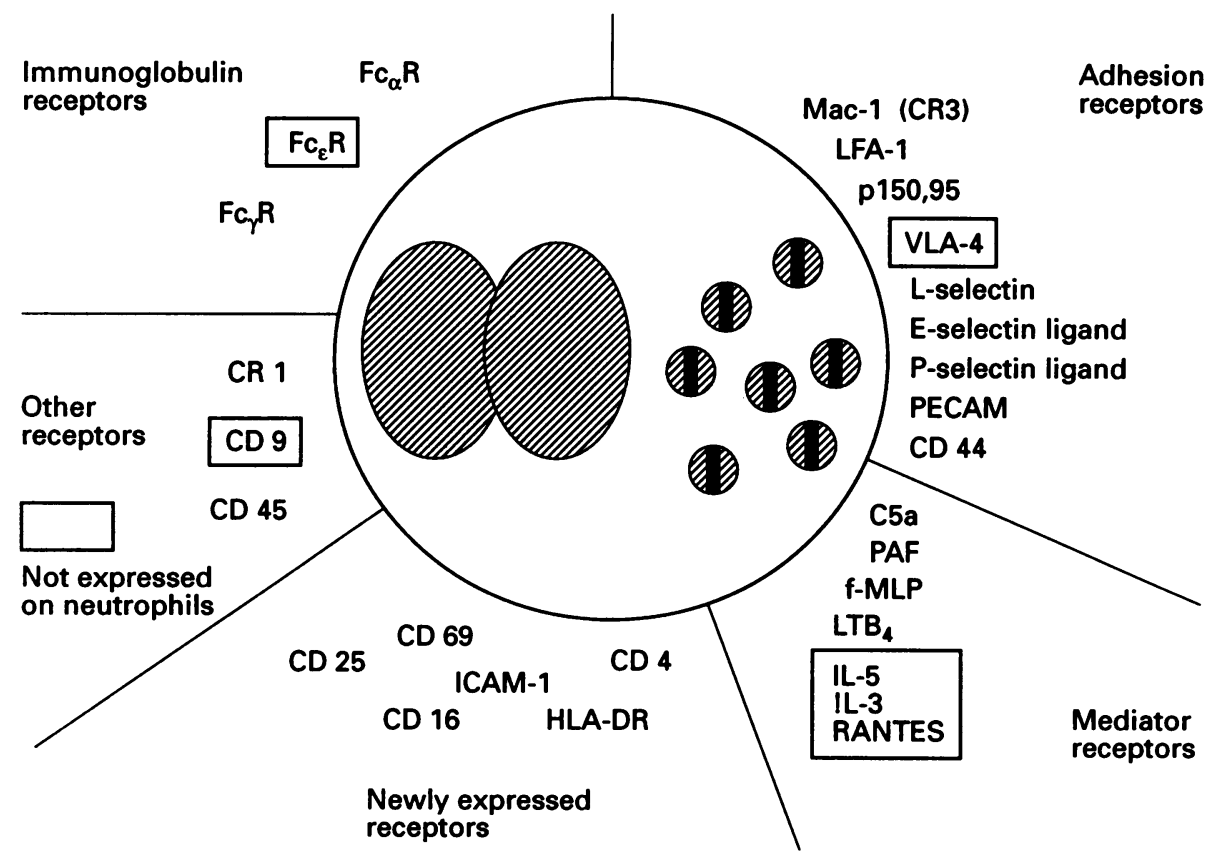

Figure 1 Schematic representation of an eosinophil with its bilobed nucleus and specific grauules illustrating the major eosinophil membrane receptors. 
Table I Eosinophil adhesion receptors and their counterstructures

\begin{tabular}{lll}
\hline $\begin{array}{l}\text { Eosinophil } \\
\text { receptor }\end{array}$ & $\begin{array}{l}\text { Endothelial } \\
\text { receptor }\end{array}$ & $\begin{array}{l}\text { Matrix } \\
\text { protein }\end{array}$ \\
\hline $\begin{array}{l}\text { Integrin } \\
\text { VLA-4 }(\alpha 4 \beta 1)\end{array}$ & VCAM-1 & $\begin{array}{l}\text { Fibronectin } \\
\text { Fibronectin }\end{array}$ \\
$\begin{array}{l}\alpha \text { VAA-6 }(\alpha 6 \beta 1) \\
\text { MadCAM-1 }\end{array}$ & ICAM-1, ICAM-2 & Faminin \\
LFA-1 & ICAM-1 & Fibrinogen \\
Mac-1 & & \\
$\begin{array}{l}\text { Immunoglobulin-like } \\
\text { PECAM }\end{array}$ & PECAM & \\
$\begin{array}{c}\text { Selectin } \\
\text { L-selectin }\end{array}$ & GlyCam-1 & \\
$\begin{array}{c}\text { Carbohydrate } \\
\text { P-selectin ligand }\end{array}$ & P-selectin & \\
E-selectin ligand & E-selectin & \\
\hline
\end{tabular}

late antigen (VLA)-4/vascular cell adhesion molecule (VCAM)-1 pathway. ${ }^{54}$ VCAM-1 expression is selectively upregulated by IL-455 and IL-4 is generated at sites of allergic inflammation. ${ }^{56} \mathrm{IL}-4$ enhances eosinophil transmigration through endothelium in a VLA-4/VCAM-1-dependent manner. ${ }^{57}$ IL-4 transgenic mice have a tissue eosinophilia and manifest an inflammatory condition in the eye similar to allergic conjunctivitis. ${ }^{58}$ Anti-VLA-4 mAb's inhibit eosinophil migration into tissue in guinea pigs. ${ }^{59}$ In contrast, VCAM-1 expression in eosinophilic tissue, such as nasal biopsies, nasal polyps, and endobronchial biopsies from asthmatic individuals and in the skin of allergic individuals after allergen challenge, is very weak or non-existent despite strong expression of other endothelial adhesion molecules. ${ }^{60,61}$ The evidence that selective expression of adhesion molecules is responsible for eosinophil localization in tissues in humans is therefore at best contradictory.

Eosinophils adhere to a number of extracellular matrix proteins. For example, fibronectin binds to eosinophils through VLA-4, laminin through VLA-6 and hyaluronate through CD44. Adhesion to matrix proteins results in priming for increased LTC4 and hydrogen peroxide release. ${ }^{62,63}$ Eosinophils also survive for prolonged periods when cultured on fibronectin, as a result of autocrine stimulation of IL-3 and GM-CSF production. ${ }^{64}$ This is a possible mechanism for prolonged survival of tissue eosinophils in both health and disease.

\section{Immunoglobulin receptors}

The eosinophil expresses receptors for IgG, IgA and IgD. The eosinophil also binds IgE and eosinophils can undertake a number of IgEdependent functions, including killing of schistomsomes opsonized with specific IgE. ${ }^{65}$ It was thought that the eosinophil IgE receptor was related to the low-affinity IgE receptor found on B-lymphocytes, platelets and macrophages - FceRIII (CD23) ${ }^{66}$ However, peripheral blood eosinophils inconsistently express messenger RNA (mRNA) for CD23 and do not stain with a panel of monoclonal antibodies (mAbs) directed against this receptor. Eosinophils express the IgE-binding protein Mac-2 but so do neutrophils that lack IgE-dependent functions. ${ }^{67}$ The nature of eosinophil IgE binding therefore remains to be clarified. There are three receptors for IgG: the high-affinity receptor, Fc $\gamma$ RI (CD64), and two low-affinity receptors, Fc $\gamma$ RII (CDw32) and FcyRIII (CD16) ${ }^{68}$ Only CD32 is constitutively expressed by eosinophils to any significant degree. ${ }^{42}$ A number of eosinophil functions are mediated via this receptor, including schistosomula killing, phagocytosis, the secretion of granule proteins, and the generation of newly formed, membrane-derived lipid mediators such as PAF and $\mathrm{LTC}_{4}$. After stimulation for 2 days in vitro with IFN- $\gamma$, eosinophils express CD16 and CD64 as well as CD32. ${ }^{69}$ The eosinophil also expresses IgA receptors that, when engaged by $\operatorname{IgA}$-coated Sepharose beads, trigger substantial release of eosinophil granule proteins. ${ }^{70}$

\section{Other receptors}

An interesting feature of the eosinophil is its ability to express receptors de novo after prolonged ( $>48$ hour) culture in a number of cytokines. For example, after culture in GM-CSF, eosinophils express human leucocyte antigen (HLA-DR) antigens and increased amounts of ICAM-1, which are associated with an in vitro capacity to present antigen to $\mathrm{T}$ cells. ${ }^{71}$ Peripheral blood eosinophils express the early activation antigen CD69 after cytokine stimulation in vitro as do bronchoalveolar lavage (BAL), eosinophils from patients with asthma and pulmonary eosinophilia. ${ }^{72}$ Eosinophils also respond to a number of soluble mediators such as $\mathrm{f}-\mathrm{MLP}, \mathrm{C} 5 \mathrm{a}, \mathrm{C} 3 \mathrm{a}$ and $\mathrm{RANTES},{ }^{73}$ as well as to lipid mediators such as PAF, by means of specific receptors, many of which belong to the rhodopsin family of seven transmembrane region G-proteinlinked receptors.

\section{Eosinophil chemotaxis}

A number of eosinophil chemotaxins have been described, although few are both effective and specific. PAF and C5a are highly active on human eosinophils but are equally active on neutrophils. ${ }^{74}$ $\mathbf{L T B}_{4}$ and 5,15,diHETE act as guinea pig eosino- 
phil and neutrophil chemoattractants. ${ }^{75}$ IL-5; IL-3 and GM-CSF have variable and generally weak activity in the Boyden chamber assay, although they are active at very low concentrations. ${ }^{76}$ They are only active on eosinophils from individuals with normal eosinophil counts. However, they can effectively prime eosinophils for enhanced chemotactic responsiveness to suboptimal concentrations of PAF and $\mathrm{LTB}_{4}$, as well as enhancing the generally negligible activity that f-MLP and IL-8 have for unactivated eosinophils. ${ }^{77}$ Recently, it has been reported that the C-C chemokine RANTES is an effective and selective (in the sense of having no activity for neutrophils) chemoattractant for eosinophils. ${ }^{73}$ In vivo PAF injected into the skin caused the accumulation of eosinophils in atopic individuals, but neutrophils were prominent in non-atopic subjects. ${ }^{78}$ Increased numbers of neutrophils, but not eosinophils, appeared in BAL fluid 4-6 hours after the inhalation of PAF in a group of eight normal subjects, three of whom were atopic. ${ }^{79}$ A highly effective but non-specific mediator such as PAF could combine with a selective but weakly chemotactic agent such as IL-5 to promote the specific accumulation of eosinophils in allergic disease. Inhalation of $\mathrm{LTE}_{4}$ produced eosinophil migration into the airways. ${ }^{80}$ The mechanism of this effect is not clear.

\section{Eosinophil mediators}

Eosinophils have the capacity to secrete a number of potent mediators (Figure 2). These include basic proteins stored in eosinophil granules, lipid mediators newly formed ater eosinophil activation, $\stackrel{?}{\rightarrow}$ cytokines, various eosinophil proteases, and com- $\frac{\partial}{\partial}$ ponents of the oxygen burst, including superoxide and hydrogen peroxide.

\section{Lipid mediators}

Eosinophils generate an array of lipid mediators principally eicosanoids and PAF. ${ }^{81}$ Eosinophils can $\overrightarrow{\vec{\omega}}$ generate relatively large amounts (up to $70 \mathrm{ng} / 10^{6}$ cells) of the sulphidopeptide leukotriene, $\mathrm{LTC}_{4}, \underset{8}{\overrightarrow{0}}$ after stimulation with the calcium ionophore, but 3 . only negligible amounts of $\mathrm{LTB}_{4}{ }^{82}$ This is in contrast to neutrophils which can produce large amounts of $\mathrm{LTB}_{4}$, but little, if any $\mathrm{LTC}_{4} . \mathrm{LTC}_{4} \stackrel{\mathrm{N}}{\mathrm{\sigma}}$ generation by human eosinophils was also of observed after stimulation with both opsonized $\mathscr{\sigma}^{\circ}$ zymosan and via an FcyII-dependent mechanism $ᄋ$ using Sepharose beads coated with $\mathrm{IgG}^{44} \overrightarrow{-}$ Eosinophils can also generate substantial quan- $?$ tities of 15-HETE via 15-lipoxygenase. Eosinophils generated 25 and $2 \mathrm{ng} / 10^{6}$ cells of PAF after $\stackrel{\infty}{\square}$ stimulation with calcium ionophore and $\operatorname{Ig} g \overrightarrow{0}$

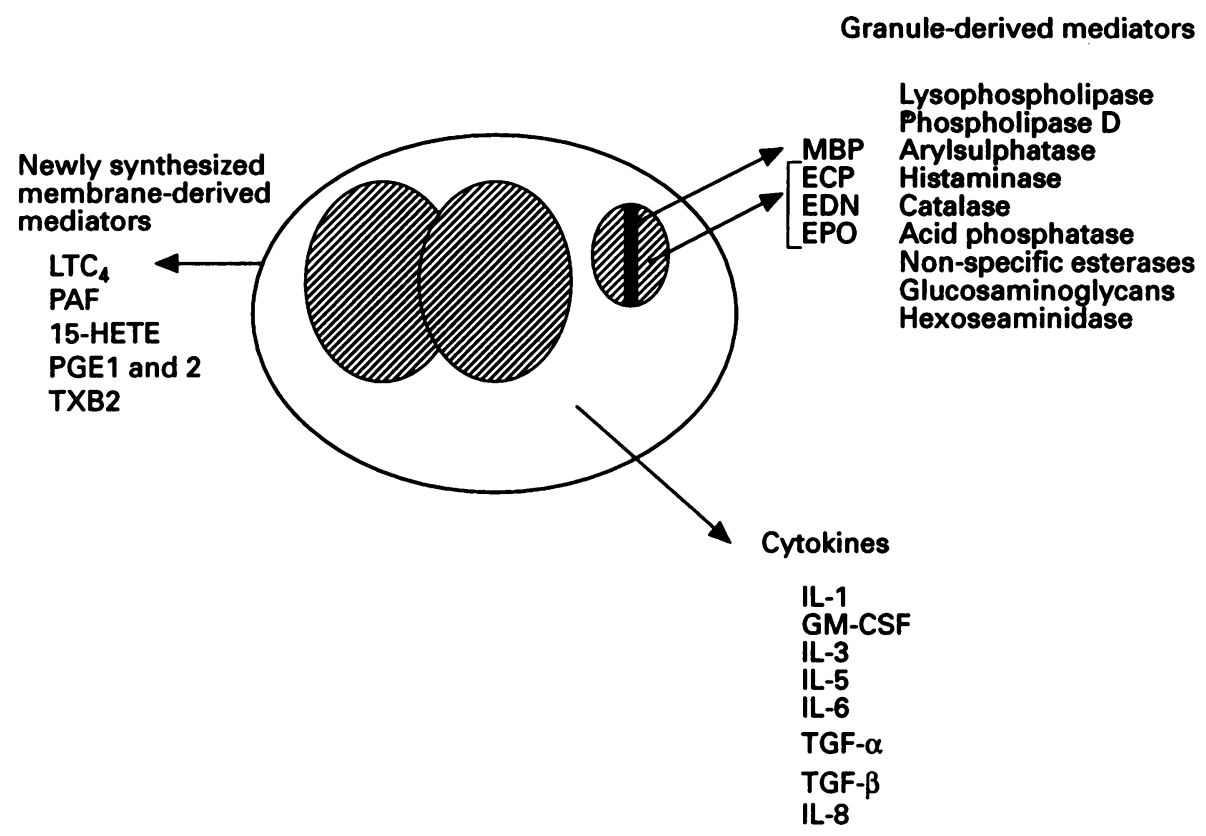

Figure 2 Schematic representation of eosinophil-derived mediators. 
coated Sepharose beads, respectively. ${ }^{45}$ Much of the PAF remained cell associated. Eosinophils can also generate mediators of the cycloxygenase pathway, including prostaglandins $E_{1}$ and $E_{2}$ and thromboxane $\mathrm{B}_{2}\left(\mathrm{TXB}_{2}\right)$.

\section{Eosinophil granule proteins}

MBP has a molecular weight of 13.801 and a pI of 10.9. It contains 17 arginine residues, which accounts for its basicity. It is initially synthesized as an acidic proprotein, which may neutralize MBP's toxicity while it is stored in the eosinophil granule. ${ }^{83}$ Purified MBP was shown to be cytotoxic for the schistosomula of $S$. mansoni, and adherence of eosinophils to IgG-coated schistosomula resulted in the secretion of MBP on to the integument of the larvae. ${ }^{84} \mathrm{MBP}$ at concentrations as low as $10 \mu \mathrm{g} / \mathrm{ml}$ has also been shown to be toxic for both guinea pig and human respiratory epithelial cells. ${ }^{85}$ The inhalation of MBP, albeit at high concentrations $(1 \mathrm{mg} / \mathrm{ml})$, produced increased bronchial hyperresponsiveness in monkeys. ${ }^{86} \mathrm{MBP}$ and EPO were shown to be strong agonists for platelet activation as well as inducing the non-cytolytic activation of mast cells, basophils and neutrophils. ${ }^{87}$ The mechanism of action of MBP is likely to be related to its hydrophobicity and strong negative charge.

EPO is a heme-containing protein composed of a $14,000 \mathrm{Da}$ (light) and a 58,000 Da (heavy) subunit derived from the same strand of mRNA and subsequently cleaved. The cDNA also demonstrates the presence of a prosequence. ${ }^{88} \mathrm{EPO}$ shares a $68 \%$ amino-acid identity with human neutrophil myeloperoxidase as well as other peroxidase enzymes. EPO is toxic for parasites, respiratory epithelium, and pneumocytes, either alone, or (more potently) when combined with $\mathrm{H}_{2} \mathrm{O}_{2}$ and halide, the preferred ion in vivo being bromide.

$\mathrm{ECP}$ is an arginine-rich protein with a $\mathrm{pI}$ of 10.8 of 133 amino acids with a molecular mass of $15.6 \mathrm{kDa}$ ECP shows $66 \%$ amino-acid homology with EDN and $31 \%$ homology with human pancreatic ribonuclease. ${ }^{89}$ It has low ribonuclease activity compared to EDN. It appears to be expressed only in eosinophils or eosinophilic cell lines. ECP is toxic for helminthic parasites, isolated myocardial cells, and guinea pig tracheal epithelium. ECP also inhibits lymphocyte proliferation in vitro. Both ECP and EDN produce neurotoxicity (the Gordon phenomenon) when injected into the cerebrospinal fluid of experimental animals. The secreted form of ECP differs structurally and antigenically from the stored form. This difference has been used to differentiate between resting eosinophils and activated eosinophils in which active secretion is occurring with the $\mathrm{mAb}$ EG1 recognizing the stored form and the mAb EG2, the activated state. ${ }^{90}$
EDN, also called EPX, is a $16 \mathrm{kDa}$ glycosylated protein possessing marked ribonuclease activity. Like ECP, it is a member of ribonuclease multigene family. ${ }^{91}$ EDN expression is not restricted to eosinophils, as it is found in mononuclear cells and possibly neutrophils. It is also probably secreted by the liver. It does not appear to be toxic to parasites or mammalian cells and its only known function, other than its ribonuclease activity, is the neurotoxicity exhibited in the Gordon phenomenon.

A major constituent of eosinophil is CLC protein which has been shown to be lysophospholipase. It constitutes up to $10 \%$ of eosinophil protein and is also found in large quantities in basophils, thus highlighting the similarities between these two cell types. Its function is unclear. ${ }^{92}$

\section{Cytokines}

Eosinophils can synthesize an array of cytokines. Activated eosinophils have been shown to secrete significant amounts of transforming growth factoralpha (TGF- $\alpha){ }^{93}$ After stimulation with calcium ionophore, eosinophils can also generate GM-CSF and IL-3, which prolong eosinophil survival as well as IL-8. ${ }^{94-96}$ Eosinophils in allergic tissue expressed mRNA for IL-5 and eosinophils have been shown to generate significant quantities of TGF $\beta$ and IL-6. ${ }^{97-99}$ IL-1 has also been detected in human eosinophils.

\section{Other mediators}

The eosinophil contains a number of granulestored enzymes whose role in eosinophil function is not clear (reviewed by Spry ${ }^{100}$ ). They include acid phosphatase (large amounts of which have been isolated from eosinophils), collagenase, arylsulphatase $B$, histaminase, phospholipase $\mathrm{D}$, catalase, non-specific esterases, vitamin $B_{12}$-binding proteins and glycosaminoglycans. Eosinophils can undergo a respiratory burst with release of superoxide ion and $\mathrm{H}_{2} \mathrm{O}_{2}$ in response to stimulation.

\section{Eosinophil secretion and activation}

A striking feature of eosinophil-rich inflammatory reactions is the marked deposition of granule proteins often in the presence of relatively small numbers of intact eosinophils. The mechanism of eosinophil secretion in vivo is still poorly understood. Eosinophils are cytotoxic for the larvae of helminthic parasites such as schistosomulae of $S$. mansoni but only when the larvae have been opsonized with either complement or immuno- 
globulin suggesting that triggering of eosinophil secretion is dependent on perturbation of $F c y$ or complement receptors, particularly Mac-1. Eosinophils preferentially secrete their mediators on to a large surface, a process described as frustrated phagocytosis. Opsonized zymosan interacts with eosinophils, triggering generation of hydrogen peroxide and PAF through Mac-1. ${ }^{101}$ The ability of eosinophils to secrete their mediators is markedly enhanced by priming with soluble mediators such as chemotactic factors and cytokines. Chemotactic agents can also elicit the direct secretion of both granule proteins and lipid mediators, although soluble mediators are generally ineffective secretogogues except with highly activated eosinophils or when used in conjunction with cytochalasin B, which inhibits cytoskeletal assembly. ${ }^{102}$ Differential secretion of granule proteins depending on the stimulus has been reported. Immunoglobulin G (IgG) complexes induced the secretion of ECP but not EPO, whereas IgE complexes induced secretion of EPO but not ECP. ${ }^{103}$ However, secretion was low in both instances. Eosinophils release their granule components by exocytosis, with individual granules fusing with the plasma membrane. This process involves a guanosine $5^{\prime}$-triphosphate (GTP)binding protein and is modulated by the intracellular calcium concentration. ${ }^{104}$ Priming of eosinophils involves a rise in intracellular calcium and triggering of PI turnover. As is the case with degranulation, the signal transduction pathways involved in priming appear broadly similar to those described for mast cells and neutrophils. ${ }^{105}$

Several cytokines have a marked effect on eosinophil function. IL-5, besides being a growth maturation factor for eosinophils, also selectively stimulates a number of mature human eosinophil functions, including prolonged survival, cytotoxicity toward helminth targets, and increased adhesion to vascular endothelium. ${ }^{106}$ IL-3 and GM-CSF have similar though less selective activities. IFN- $\gamma$ stimulates eosinophil cytotoxicity, prolongs eosinophil survival and results in expression of mRNA for GM-CSF. TNF- $\alpha$ stimulated eosinophil cytotoxicity toward endothelium. ${ }^{107}$ IL3, IL-5 and GM-CSF have both short-term priming effects on eosinophils, which are maximal within an hour and more long-term effects, which include increased receptor expression and depend on protein synthesis.

\section{Eosinophilia}

An isolated count of eosinophil numbers in the blood offers only a limited and sometimes misleading picture of eosinophil involvement in a particular disease. The blood eosinophil count $\frac{2}{z}$ represents the balance between the rate of eosinophil migration from the bone marrow and $\bar{c}$ entry into the tissues. Once in the tissue, eosinophils can survive for many days under the $\stackrel{9}{?}$ influence of locally generated cytokines. Their removal appears to be largely the result of pro- $\frac{\overline{ }}{\bar{T}}$ grammed cell death (apoptosis) and subsequent $\frac{\infty}{\vec{D}}$ phagocytosis of the senescent cell by macro- $\propto$

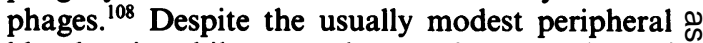
blood eosinophil counts, there are large numbers of eosinophils and their precursors in the normal bone marrow.

Eosinophils can be enumerated in the peripheral blood either by 'wet counts' in modified Neubauer chambers, differential counts on dried smears or by automated cell counting. The automated counting $\partial$ that uses detection of eosinophil peroxidase is the 0 most accurate method followed by counting in a $\sigma$ cell chamber. Counting on smears is least accurate $\mathcal{E}$ because of the tendency for eosinophils to congre- O gate at the margins of the smear. It is preferable to $\frac{\text { ㅇ }}{3}$ record the eosinophil count in absolute numbers rather than as a percentage, as the latter will depend on the total cell count. The normal eosinophil count is (generally taken as) less than $0.4 \times 10^{9} / 1$, although a study of 765 medica $\vec{\varphi}$ students in the USA measured counts ranging from $0.015-0.65 \times 10^{9} / 1 .^{109}$ It is higher in neonates. The eosinophil count varies with age, time of day, exercise and environmental stimuli, particularly allergen exposure. Blood eosinophil counts undergo diurnal variation, being lowest in the morning and highest at night. This effect resulted in a greater than $40 \%$ variation in one study. ${ }^{111}$ This may be related to the reciprocal diurnal variation in cortisol levels which are highest in the morning.

The causes of an eosinophilia can be usefully classified according to the degree and frequency of occurrence (Table II). Division of eosinophil counts into degree is arbitary but a mild eosinophilia could be regarded as $0.4-1.5 \times 10^{9} / 1$, a moderate count as $1.5-5 \times 10^{9} / 1$ and a high count as greater than $5 \times 10^{9} / 1$. The commonest cause of an eosinophilia worldwide is infection with helminthic parasites, which can often result in a very high count. The commonest causes of an eosinophilia in industrialized countries are the atopic allergic o diseases, seasonal and perennial rhinitis, atopic dermatitis and asthma. Allergic disease generally results in only a mild increase in eosinophil counts. A moderate or high eosinophil count in asthma raises the possibility of a complication such as Churg-Strauss syndrome or allergic bronchopulmonary aspergillosis (ABPA). Apart from allergic disease and helminthic parasites, a raised eosinophil count, especially a moderate or high count, is unusual. 


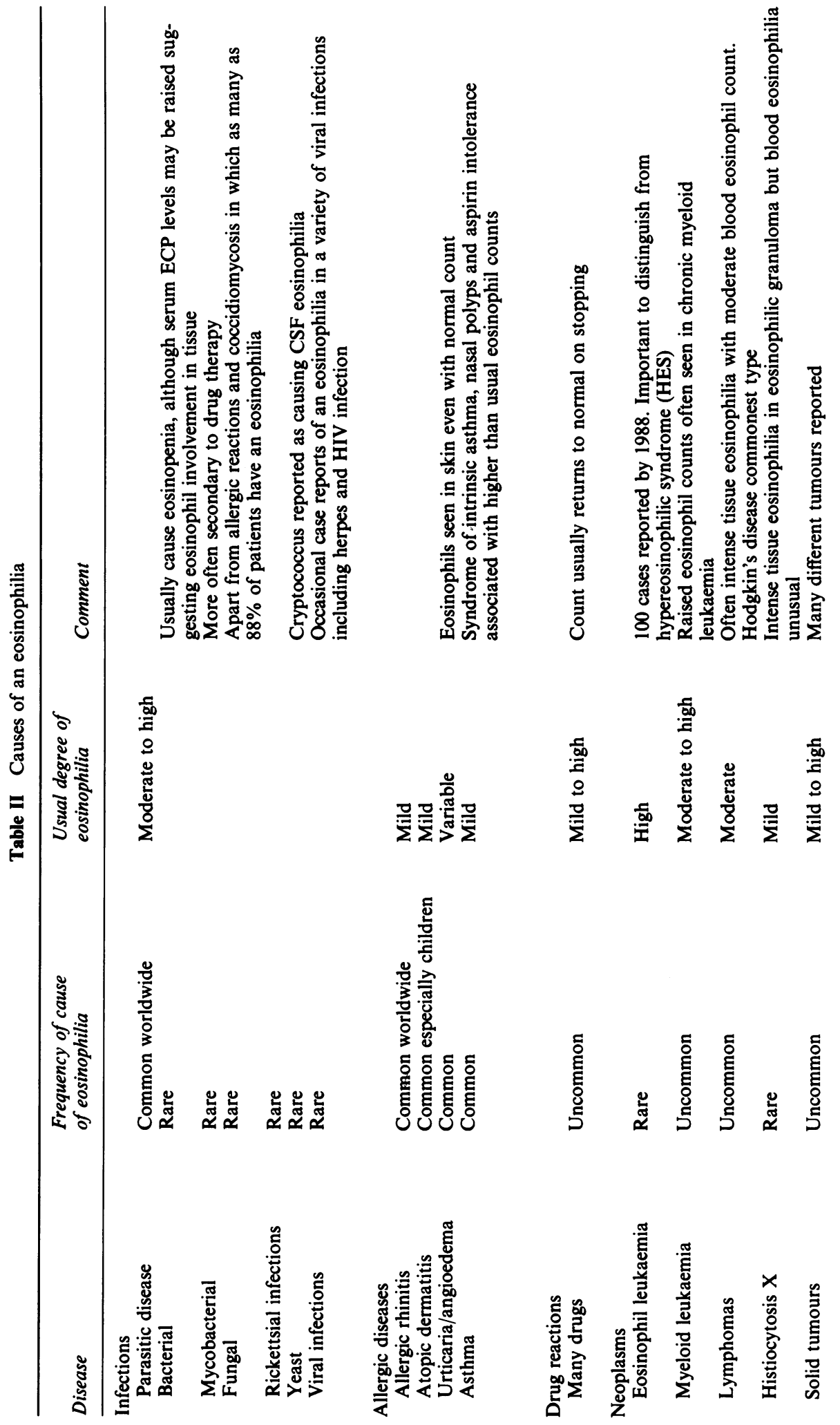

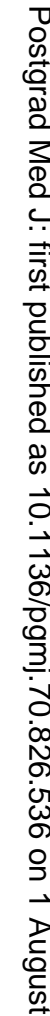

要

웅

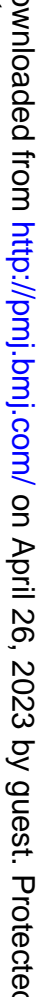




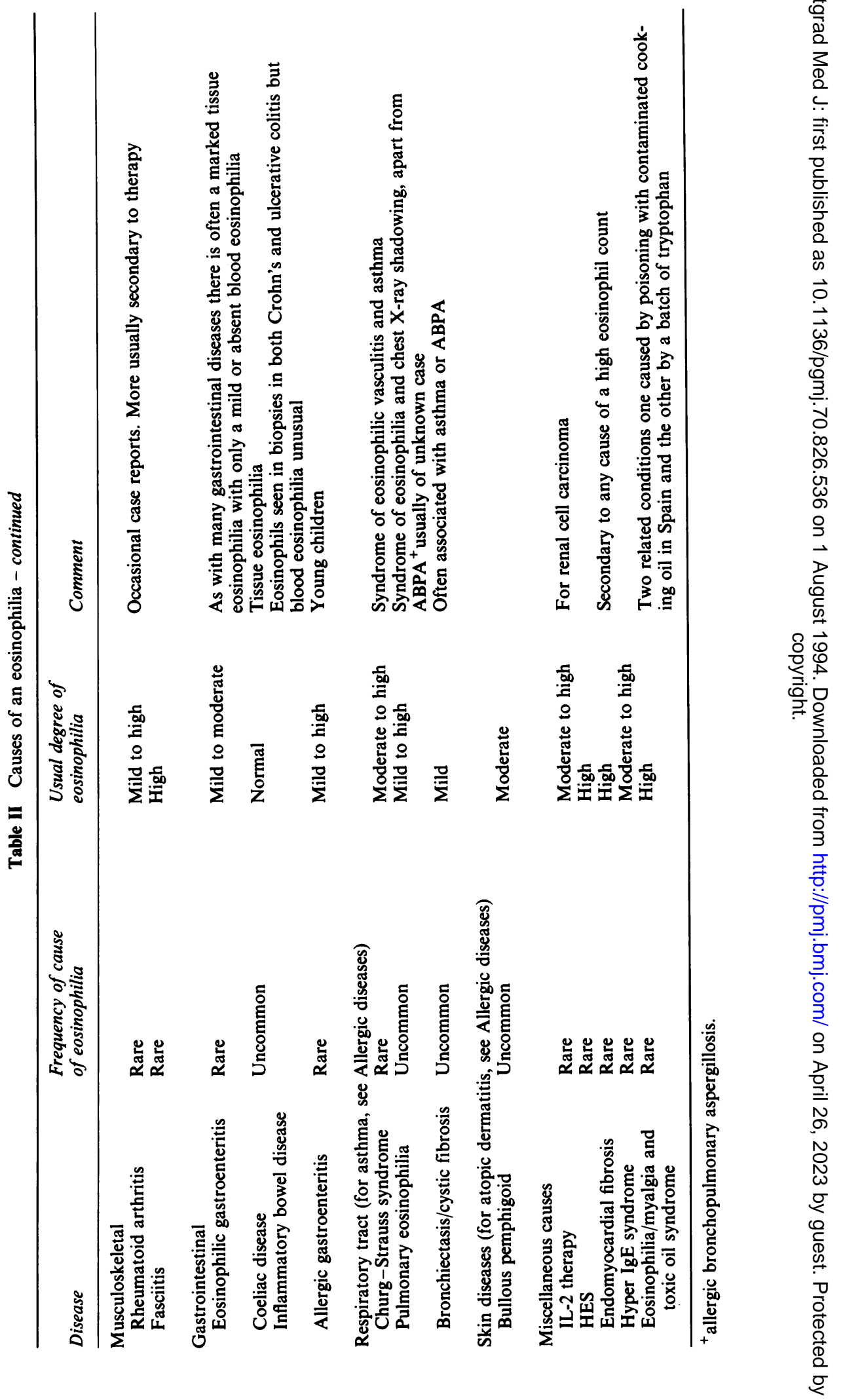




\section{Eosinophils and disease}

\section{The role of eosinophils}

Views on the role of eosinophils in health and disease have changed with time. For years they were thought to ameliorate inflammatory responses, now they are believed to have a tissuedamaging role. ${ }^{112,113}$ Even more recently it has become apparent that eosinophils are the source of a range of cytokines several of which are thought to have a homeostatic, rather than pro-inflammatory function. For example, the observation that eosinophils secrete TGF $\alpha$ together with studies showing increased numbers of eosinophils at the edges of healing wounds suggests that they may be important in wound healing. ${ }^{114}$ Cytokinestimulated eosinophils secrete IL-1, express HLA class II receptors and present antigen to $\mathrm{T}$ cells in vitro, suggesting they may be important as accessory cells in T-cell-mediated reactions. There is evidence that eosinophils slow the rate of progression of solid tumours, presumably by being cytotoxic against tumour cells. ${ }^{115}$ Nonetheless, there is also little doubt that eosinophils can cause severe tissue damage under certain circumstances. Persistently high eosinophil counts from many causes including drug reactions, parasitic infections, eosinophilic leukaemia and hypereosinophlic syndrome are associated with endomyocardial fibrosis, a condition that presents with heart failure and signs consistent with a restrictive cardiomyopathy. The ventricle is thickened and histologically there are areas of fibrosis, thrombus formation and inflammation in the endomyocardium with large numbers of both intact and degranulating eosinophils. Eosinophil granule products are deposited adjacent to myocytes and in vitro have been shown to be toxic for cardiac myocytes. HES is a condition in which there is a high eosinophil count of unknown aetiology and it is associated with a number of features, several of which could be ascribed to the toxic properties of eosinophils. ${ }^{116}$

Much of the work undertaken in recent years on eosinophils has been in association with allergic disease and parasitic infection. The observation in the mid-1970s that eosinophils could kill parasite targets led to the hypothesis that the teleological role of eosinophils was to counter parasitic infection. ${ }^{117}$ The realization that eosinophils could release pro-inflammatory mediators such as PAF and eiconsanoids, and the observation that eosinophil basic proteins were toxic for airway epithelium has led to a consensus that eosinophils are a major effector cell for tissue damage in asthma and could cause many of the pathological features of the disease. These conditions provide a useful model for eosinophil involvement in disease processes.

\section{Eosinophils and asthma}

It is well established that large numbers of eosinophils together with mononuclear cells are frequently found in and around the bronchi with patients who have died of asthma. The immunostaining of bronchial tissue from such patients has revealed the existence of large amounts of MBP deposited in the airways. ${ }^{118}$ The presence of increased numbers of peripheral blood eosinophils in both atopic and non-atopic chronic asthma is well known, although this elevation is not as great as that seen in other eosinophil-associated diseases and the peripheral blood eosinophil count is often normal.

Full appreciation of the extent of eosinophil involvement in asthma has come with the use of fibreoptic bronchoscopy to obtain BAL fluid and endobronchial biopsies from the airways in patients with mild to moderate asthma. Aerosolized challenge of sensitized asthmatics with allergen results in an influx of inflammatory cells consisting of eosinophils, neutrophils and mononuclear cells into the airways and an increase in the amount of eosinophil granule proteins in lavage fluid. ${ }^{119} \mathrm{~A}$ similar picture has been observed after challenge with agents that cause occupational asthma. ${ }^{120.121}$ The eosinophilia associated with segmental challenge down the bronchoscope is even more dramatic. Twenty-four hours after segmental challenge up to $50 \%$ of the lavage cells were eosinophils. ${ }^{122}$ Similar findings have been found after allergen challenge to the skin and nose. ${ }^{123,124}$

An almost invariable increase in the number of eosinophils, in association with increased numbers of mast cells and epithelial cells has been observed in BAL fluid and endobronchial biopsies from clinical asthmatics compared with normal controls. ${ }^{125-128} \mathrm{~A}$ lesser, but often significant, increase in airway eosinophils is seen in atopic non-asthmatics or seasonal asthmatics out of season. Airway eosinophils in asthma are activated as determined by staining with $\mathrm{mAb}$ EG2 and expression of the activation receptor CD69. ${ }^{129,130}$ Eosinophil infiltration is accompanied by increased numbers of activated CD25-positive T-lymphocytes, which have a Th2-like profile of cytokine secretion ${ }^{131}$ and evidence of epithelial desquamation with increased numbers of epithelial cells in BAL fluid and signs of epithelial fragility in bronchial biopsies. ${ }^{132}$ The increase in eosinophils has been noted in intrinsic and occupational asthma as well as atopic asthma. ${ }^{133,134}$ A BAL eosinophilia is relatively specific to asthma, although it is also seen in pulmonary eosinophilia and some patients with fibrosing alveolitis. ${ }^{135}$ The numbers of eosinophils in BAL fluid in asthma are generally only modestly raised ranging from $1 \%$ to $5 \%$ (normals, $<1 \%$ ), 
although occasionally eosinophil counts can be in the range of $30-50 \%$. There is a general correlation between the numbers of airway eosinophils and the severity of asthma. ${ }^{136}$ Inhibition of an airway eosinophilia by disodium chromoglycate (DSCG), ${ }^{137}$ or more effectively corticosteroids, ${ }^{138,139}$ is associated with an improvement in bronchial hyperresponsiveness, symptoms and lung function. Inhibition of migration of eosinophils into the airways of allergen-challenged non-human primates, using an monoclonal antibody directed against the adhesion molecule ICAM-1, also inhibited the development of airway hyperresponsiveness. ${ }^{140}$ However, none of these treatments is specific to the eosinophil. Glucocorticoids, for example, probably act to a large extent through inhibition of the release of eosinophil active cytokines from T-cells and monocytes. ${ }^{141}$ Airway eosinophilia can also occur without asthma or airways hyperresponsiveness. ${ }^{142}$ For eosinophils to cause tissue damage in the airways, they need to be actively secreting their mediators. Measurements of eosinophilic basic proteins may therefore be a better guide to the degree of eosinophilic inflammation than eosinophil numbers. For example, Adelroth and coworkers found that, whereas inhaled corticosteroids had no effect on the number of eosinophils in BAL fluid from asthmatics, they markedly reduced the amounts of ECP in lavage fluid. ${ }^{143}$

\section{Eosinophils and parasitic disease}

Although infection with helminths is by far the commonest cause of a moderate to high eosinophilia in association with parasites, eosinophilia in association with protozoan infections has been described and ectoparasites such as head lice and scabies can produce a local eosinophilic reaction. The commoner helminthic causes of an eosinophilia are summarized in Table III. ${ }^{144-146}$ Eosinophils have been shown to be able to kill a number of opsonized parasites including newborn larvae of $T$. spiralis, larvae of Nippostrogylus brasiliensis, a gut parasite in the rat, and $F$. hepatica as well as schistosomulae of $S$. mansoni. ${ }^{147}$ In vivo parasite larvae become coated with specific IgG and IgE antibodies and can activate complement. Dead larvae of $S$. haematobium and other parasites have been detected surrounded by eosinophils and eosinophil granule products in the skin. ${ }^{148}$ Adult worms both in vitro and in vivo appear resistant to eosinophil-mediated damage. Despite this circumstantial evidence for eosinophils being involved in host defence against parasites, there remains some doubt about their role. Except for one study in the Gambia ${ }^{149}$ there is no obvious correlation between the degree of eosinophilia and protection against infection or reinfection. Moreover, treatment of mice infected with $N$. brasiliensis or $S$. mansoni with neutralizing anti-IL-5 mAbs abolished the eosinophilia without modulating the disease process. ${ }^{150}$

\section{Other eosinophilic disorders}

More unusual eosinophilic disorders include pulmonary eosinophilia, idiopathic hypereosinophilic syndrome, eosinophil leukaemia and ChurgStrauss syndrome, which is a life-threatening condition characterized by eosinophilic vasculitis, o asthma and a peripheral blood eosinophilia. ${ }^{151}$ These conditions are of unknown aetiology. Management generally consists of treatment with highdose oral glucocorticoids supplemented by chemotherapy, if the condition is only partially responsive, as is generally the case in HES and Churg-Strauss syndrome. More recently therapy with interferon $\alpha$ and $\gamma$ has been used with anecdotal success in HES. IL-5 antagonists, when they become available, may also be effective. Two interesting and related conditions that have been described recently are toxic oil syndrome (TOS) and eosinophilia-myalgia syndrome. ${ }^{152}$ Eosinophilia-myalgia syndrome was first described in October 1989 in New Mexico and 1,500 cases were reported by mid-1990 with 27 deaths. It was caused by ingestion of a batch of tryptophan and though to be due to a contaminant possibly $1,1^{\prime}$-ethy idenebis (tryptophan). It was characterized by severe myalgia in association with an eosinophil count of greater than $1 \times 10^{9} / 1$ with a median count of 4-6 $\times 10^{9} / 1$. Patients also complained of fatigue, shortness of breath, cough, rash and headache. Histopathologically there was a perivascular lymphocyte and eosinophilic infiltrate in the dermis, fascia and skeletal muscle with a pulmonary vasculitis and alveolitis. The histological appearances were similar to eosinophilic fascilitis. Symptoms were persistent and not very responsive to treat ment with glucocorticoids and immunosuppressants. TOS was an epidemic in Spain in 1981 caused by the ingestion of industrial rapeseed oil. A total of 20,000 people were affected with 300 deaths. The acute phase of TOS was characterized by an adult respiratory distress syndrome-(ARDS) likc picture with a profound eosinophilia but the chronic phase resembled eosinophilia-myalgia syndrome both clinically and histopathologically. Fifty per cent of patients had complete resolution after 8 years. The precise aetiological agent is unknown.

\section{Eosinopenia}

The normal eosinophil count is often low, although in one study of over 20,000 patients only 24 had 


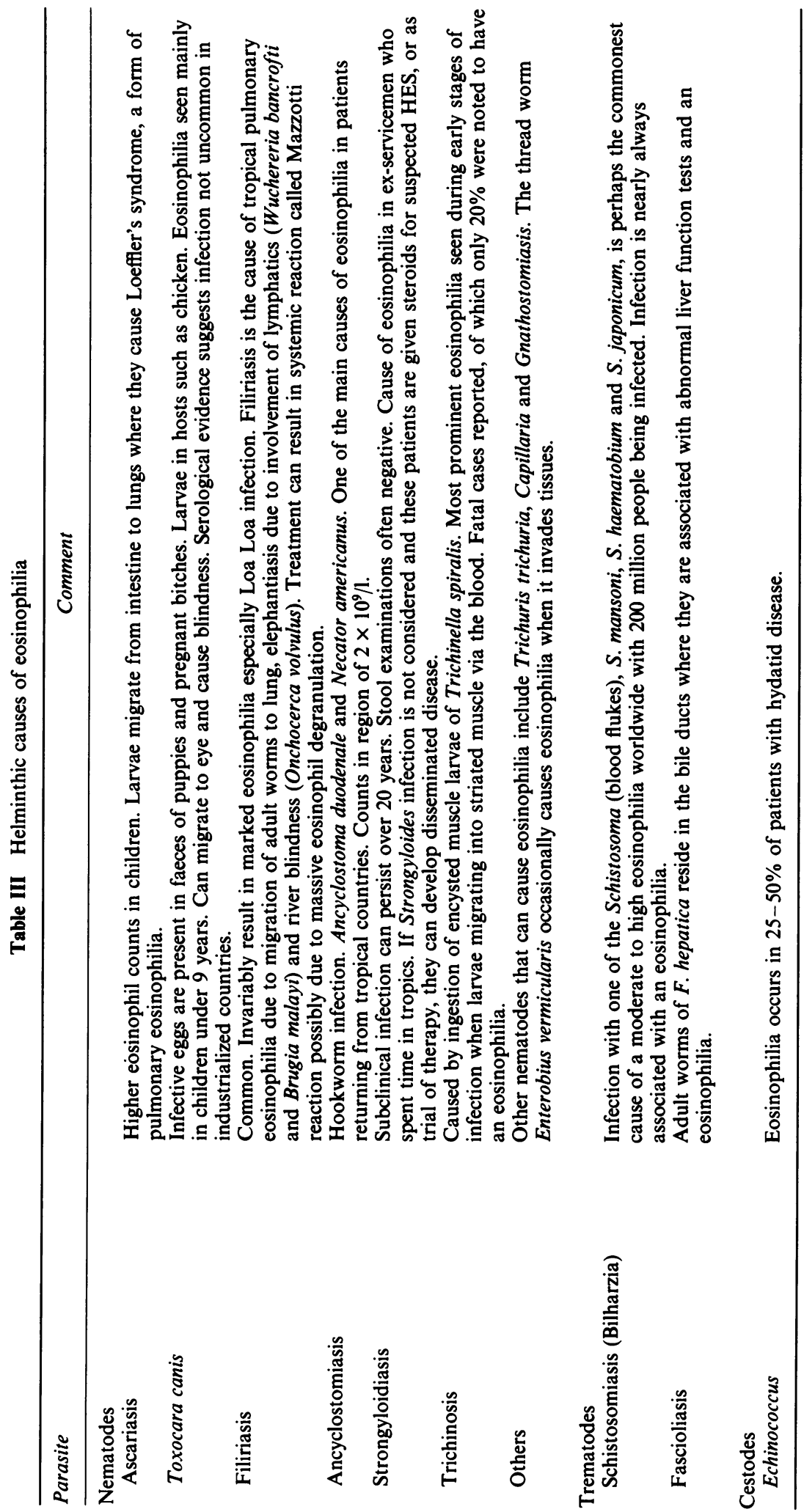


counts of less than $0.01 \times 10^{9} / 1$. In each case this could be ascribed to the disease or treatment. ${ }^{3}$ Acute infections, treatment with glucocorticoids and adrenaline decrease eosinophil counts. In contrast, $\beta$ blockers inhibit adrenaline-induced eosinopenia and can cause a rise in the eosinophil count. The mechanism by which eosinopenia occurs in these circumstances is not fully understood. Beeson and Bass found that acute infection in mice resulted in a rapid fall in eosinophil counts due to either margination or migration into tissue and a more prolonged eosinophilia due to inhibition of bone marrow production. A soluble mediator of greater than $30,000 \mathrm{kDa}$ appeared to be involved. ${ }^{153}$ There have been several isolated case reports of patients with absent eosinophils in the blood and bone marrow. ${ }^{154}$ Often the cause of the eosinopenia was related to some immunological problem. For example, in one case it occurred after drug-induced agranulocytosis ${ }^{155}$ and in another there was a serum inhibitor of eosinophil colony formation. ${ }^{156} \mathrm{~A}$ rare disorder is EPO deficiency, cases of which may be brought to light by automatic counting that uses detection of EPO to count eosinophils. EPO deficiency does not appear to have any adverse clinical consequences. ${ }^{157}$

\section{Summary and conclusions}

Eosinophils are characterized by their unique crystalloid granules that contain four basic proteins MBP, ECP, EDN and EPO. The cell has many common features with neutrophils but, unlike that

\section{References}

1. Ehrlich, P. Ueber die specifischen granulationen des Blutes. Arch Anat Physiol Lpz 3 Physiol Abt 1879, 571-579.

2. Spry, C.J.F. Eosinophils, A Comprehensive Review and Guide to the Medical Literature. Oxford University Press, Oxford, 1988.

3. Smith, H. \& Cook, R.M. (eds) Immunopharmacology of Eosinophils. Academic Press, London, 1993.

4. Makino, S. \& Fukuda, T. (eds) Eosinophils, Biological and Clinical Aspects. CRC Press, Boca Raton, FL, 1993.

5. Gleich, G.J. \& Kay, A.B. (eds) Eosinophils in Allergy and Inflammation. Marcel Dekker, New York, 1994.

6. Sokol, R.J., Hudson, G., Wales, J. \& James, N.T. Ultrastructural morphometry of human leukocytes in health and disease. Electron Microsc Rev, 1991, 4: 179-195.

7. Egesten, A., Alumets, J., von Mecklenburg, C., Palmegren, M. \& Olsson, I. Localization of eosinophil cationic protein, major basic protein and eosinophil peroxidase in human eosinophils by immunoelectron microscopic technique. $J$ Histochem Cytochem 1986, 34: 1399-1403.

8. Weller, P.F., Monahan-Earley, R.A., Dvorak, H.F. \& Dvorak, A.M. Cytoplasmic lipid bodies of human eosinophils. Subcellular localization and analysis of arachidonate incorporation. Am J Pathol 1991, 138: 141-148. cell type, eosinophils utilize VLA-4/VCAM-1 as an adherence pathway and have a number of other receptors not shared by neutrophils. These include recognition units for IgE (distinct from CD23), and receptors for IL-5, IL-3 and RANTES. Following stimulation with a variety of agents, eosinophils preferentially elaborate $\mathrm{LTC}_{4}$ as the major 5lipoxygenase product of arachidonic acid and produce substantial amounts of PAF. Of particular interest is the ability of eosinophils to synthesize a number of cytokines. Thus eosinophils have marked pro-inflammatory potential.

There is now convincing evidence that eosinophilia is T-cell dependent. The Th2-type cell, which selectively secretes IL-5 and IL-4, seems particularly involved. IL-5, IL-3 and GM-CSF are required for eosinophil maturation, and cause activation and prolonged survival of the mature cell. IL-5 is unique in that it promotes terminal differentiation of the committed eosinophil precursor and in vivo in mice appears to be sufficient on its own for eosinophil growth from uncommited stem cells. IL-4 selectively upregulates VCAM-1 expression on endothelial cells thus augmenting VLA-4 dependent eosinophil adhesion. The role of eosinophils in disease is complex but in general their numbers are increased in helminthic parasitic disease and atopic allergy and asthma. Eosinophit products can produce many of the pathologicat features of asthma, and helminthic larvae coatef with immunoglobulin or complement are parto icularly susceptible to eosinophil-mediated cytotoxicity. Eosinopenia is often related to acute inflammation or stress.

9. Dvorak, A.M., Letourneau, L., Login, G.R., Weller, P.F. \& Ackerman, S.I. Ultrastructural localization of the Charcot - Leyden crystal protein (lysophospholipase) to a distinct crystalloid-free granule population in mature human eosinophils. Blood 1988, 72: 150-158.

10. Parmley, R.T. \& Spicer, S.S. Cytochemical ultrastructural identification of a small type granule in human late eosinophils. Lab Invest 1974, 30: 557-567.

11. Dvorak, A.M., Ackerman, S.J. \& Weller, P.F. Subcellular morphology and biochemistry of eosinophils. In Harris, J.R. (ed.) Blood Cell Biochemistry: Megakaryocytes, Platelets, Macrophages and Eosinophils, Vol. 2. Plenum Publishing, London, 1991, pp. 237-344

12. Spry, C.J.F. The natural history of eosinophils. In: Smith, H. \& Cook, R.M. (eds.) The Immunopharmacology of Eosinophils. Academic Press, London, 1993, pp. 1-9.

13. Saito, H., Hatake, K., Dvorak, A.M. et al. Selective $O$ differentiation and proliferation of hematopoietic cells induced by recombinant human interleukins. Proc Natl Acad Sci USA 1988, 85: 2288.

14. Baston, A. \& Beeson, P.B. Mechanism of eosinophilia. II Role of the lymphocyte. J Exp Med 1970, 131: 1288-1305. 
15. Hsu, C.K., Hsu, S.H., Whitney, R.A. \& Hansen, C.T. Immunopathology of schistosomiasis in athymic mice. Nature 1976, 262: 397.

16. Leary, A.G. \& Ogawa, M. Identification of pure and mixed basophil colonies in culture of human peripheral blood and marrow cells. Blood 1984, 64: 78-83.

17. Kinashi, T., Harada, N., Severinson, E. et al. Cloning of a complementary DNA-coding T cell replacement factor and identity with B cell growth factor II. Nature 1986, 324: 70-73.

18. Campbell, H.D., Sanderson, C.J., Wang, Y. et al. Molecular cloning, nucleotide sequence and expression of the gene encoding human eosinophil differentiation factor (interleukin 5). Proc Natl Acad Sci 1987, 84: 6629-6633.

19. McKenzie, A.N.J., Ely, B. \& Sanderson, C.J. Mutated interleukin-5 monomers are biologically inactive. Mol Immunol 1991, 28: 155-158.

20. Sanderson, C.J., Campbell, H.D. \& Young, I.G. Molecular and cellular biology of eosinophil differentiation factor (IL-5) and its effects on human and mouse B cells. Immunol Rev 1988, 102: 29-50.

21. Tominaga, A., Takaki, S., Koyama, N. et al. Transgenic mice expressing a B cell growth and differentiation factor gene (interleukin 5) develop eosinophilia and autoantibody production. J Exp Med 1991, 173: 429-437.

22. Dent, L.A., Strath, M., Mellor, A.L. \& Sanderson, C.J. Eosinophilia in transgenic mice expressing interleukin $5 . J$ Exp Med 1990, 172: 1425-1431.

23. Saeland, S., Caux, C., Favre C. et al. Combined and sequential effects of human IL-3 and GM-CSF on the proliferation of CD34 + ve hematopoietic cells from cord blood. Blood 1989, 73: 1195 .

24. Ottman, O.G., Ganser, A., Seipelt, G., Eder, M., Schulz, G. \& Hoelzer, D. Effects of recombinant human interleukin 3 on human hematopoietic progenitor and precursor cells in vivo. Blood 1990, 76: 1494-1502.

25. Van-Leeuwen, B.H., Martinson, M.E., Webb, G.C. \& Young, I.G. Molecular organization of the cytokine gene cluster, involving the human IL-3, IL-4, IL-5 and GM-CSF genes on human chromosomes. Blood 1989, 73: 1142-1148.

26. Miyajima, A., Kitamura, T., Harada, N., Yokota, T. \& Arai, K.-I. Cytokine receptors and signal transduction. Annu Rev Immunol 1992, 10, 295-331.

27. Tavernier, J., Devos, R., Cornelis, S. et al. A human high affinity interleukin-5 receptor (IL-5R) is composed of an IL-5-specific $\alpha$ chain and a $\beta$ chain shared with the receptor for GM-CSF. Cell 1991, 66: 1175-1184.

28. Murata, Y., Takaki, S., Migita, M., Kikuchi, Y., Tominga, A. \& Takatsu, K. Molecular cloning and expression of the human interleukin 5 receptor. J Exp Med 1992, 175: 341 - 351.

29. Hamid, Q., Azzawi, M., Sun Ying et al. Expression of mRNA for interleukin- 5 in mucosal bronchial biopsies from asthma. J Clin Invest 1991, 87: 1541-1546.

30. Limaye, A.P., Abrams, J.S., Silver, J.E. et al. Regulation of parasite induced eosinophilia: selectively increased interleukin 5 production in helminth-infected patients. $J$ Exp Med 1990, 172: 399-402.

31. Enokihara, H., Furusawa, S. \& Nakakubo, H. T cells from eosinophilic patients produce interleukin 5 with interleukin 2 stimulation. Blood 1989, 73: 1809-1813.

32. Owen, W.F., Rothenberg, M.E. \& Peterson, J. Interleukin 5 and phenotypically altered eosinophils in the blood of patients with the idiopathic hypereosinophilic syndrome. $J$ Exp Med 1989, 170: 343-348.

33. Owen, W.F., Peterson, J. \& Sheff, D.M. Hypodense eosinophils and interleukin 5 activity in the blood of patients with the eosinophilia-myalgia syndrome. Proc Natl Acad Sci USA 1990, 87: 8647-8651.

34. Samoszuk, M. \& Nansen, L. Detection of interleukin-5 messenger RNA in Reed-Sternberg cells of Hodgkins disease with eosinophilia. Blood 1990, 75: 13-16.

35. Coffman, R.L., Seymour, B.W., Hudak, S., Jackson, J. \& Rennick, D. Antibody to interleukin-5 inhibits helminthinduced eosinophilia in mice. Science 1989, 245: 308-310.
36. Desreumaux, P., Janin, A., Colombel, J.F. et al. Interleukin 5 messenger RNA expression by eosinophils in the intestina mucosa of patients with coeliac disease. J Exp Med 1992 , 175: 293-296.

37. Mossman, R. \& Coffman, R.L. Th1 and Th2 cells: different patterns of lymphokine secretion lead to different functional properties. Annu Rev Immunol 1989, 7: 145.

38. Hansel, T.T., Braunstein, J.B. \& Walker, C. An improved immunomagnetic procedure for the isolation of highly purified human blood eosinophils. J Immunol Meth 1991, 145: $105-110$

39. Bass, D.A., Grover, W.H., Lewis, J.C., Szeda, P., DeChatelet, L.R. \& McCall, C.E. Comparison of human eosinophils from normals and patients with eosinophilia. $J$ Clin Invest 1980, 66: 1265-1273.

40. Caulfield, J.P., Hein, A., Rothenburg, M.E. et al. A morphometric study of normodense and hypodense human eosinophils that are derived in vivo and in vitro. Am J Pathol 1991, 137: 27-41

41. Fukuda, T. \& Makino, S. Heterogeneity and activation. In: Fukuda, T. \& Makino, S. (eds) Eosinophils Biological and Clinical Aspects. CRC Press, Baco Raton, FL, 1993, pp. 156-170.

42. Winqvist, I., Oloffson, T., Olsson, I., Persson, A.M. \& Hallberg, T. Altered density, metabolism and surface receptors of eosinophils in eosinophilia. Immunology 1982, 47: 531-539.

43. Prin, L., Capron, M., Tonnel, A.B., Blentry, O. \& Capron, A. Heterogeneity of human peripheral blood eosinophils variability in cell density and cytotoxic ability in relation to the level and origin of eosinophilia. Int Arch Allergy Clin Immunol 1983, 72: 336-346.

44. Shaw, R.J., Walsh, G.M., Cromwell, O., Moqbel, R., Spry, C.J.F. \& Kay, A.B. Activated human eosinophils generate SRS-A leukotrienes following physiological (IgG dependant) stimulation. Nature 1985, 316: 150-152.

45. Cromwell, O., Wardlaw, A.J., Champion, A., Moqbel, R., Osei, D. \& Kay, A.B. IgG-dependent generation of platelet activating factor by normal and low density eosinophils. $J$ Immunol 1990, 145: 3862-3868.

46. Owen, W.F., Rothenburg, M.E. \& Silberstein, D.S. Regulation of human eosinophil viability, density and function by granulocyte/macrophage colony stimulating factor in the presence of 3T3 fibroblasts. J Exp Med 1987, 166: 129-141.

47. Hartnell, A., Moqbel, R., Walsh, G.M., Bradley, B. \& Kay, A.B. Fc $y$ and $\mathrm{CD} 11 / \mathrm{CD} 18$ receptor expression on normal density and low density human eosinophils. Immunology 1990, 69: 264-270.

48. Hynes, R.O. Integrins: versatility, modulation and signaling in cell adhesion. Cell 1992, 69: 11-25.

49. Springer, T.A. Adhesion receptors of the immune system Nature 1990, 346: 425-434

50. Springer, T.A. \& Lasky, L.A. Sticky sugars for selectins. Nature 1991, 349, 425-434.

51. Lawrence, M.B. \& Springer, T.A. Leukocytes roll on a selectin at physiological flow rates: distinction from and pre-requisite for adhesion through integrins. Cell 1991, 65: 859.

52. Georas, S.N., Liu, M.C., Newman, W., Beall, L.D., Stealey, B.A. \& Bochner, B.S. Altered adhesion molecule expression and endothelial cell activation accompany the recruitment of human granulocytes to the lung after segmental antigen challenge. Am J Respir Cell Biol 1992, 7: 261-269.

53. Walsh, G.M., Hartnell, A., Wardlaw, A.J., Kuirhara, K. Sanderson, C.J. \& Kay, A.B. IL-5 enhances the in vitro adhesion of human eosinophils, but not neutrophils, in a leukocyte integrin (CD11/18)-dependent manner. Immunology 1990, 71: 258-265.

54. Walsh, G.M., Hartnell, A., Mermod, J.-J., Kay, A.B. \& Wardlaw, A.J. Human eosinophil but not neutrophil adherence to IL- 1 stimulated HUVEC is a $4 / \mathrm{bl}$ dependent. $J$ Immunol 1991, 146: 3419-3423. 
55. Thornhill, M.H., Kyan-Aung, U. \& Haskard, D.O. IL-4 increases human endothelial cell adhesiveness for $T$ cells but not neutrophils. J Immunol 1990, 144: 3060.

56. Kay, A.B., Ying Sun, Varney, V. et al. Messenger RNA expression of the cytokine gene cluster IL-3, IL-4, IL-5 and GM-CSf in allergen-induced late-phase cutaneous reactions in atopic subjects. $J$ Exp Med 1991, 173: 775-778.

57. Moser, R., Fehr, J. \& Bruijnzeel, P.B. IL-4 controls the selective endothelium-deriven transmigration of eosinophils from allergic individuals. J Immunol 1992, 149: 1432- 1438.

58. Tepper, R.I., Levinson, D.A., Stanger, B.Z., CamposTorres, J., Abbas, A.K. \& Leder, P. IL-4 induces allergic-like inflammatory disease and alters $T$ cell development in transgenic mice. Cell 1990, 62: 457-467.

59. Weg, V.B., Williams, T.J., Lobb, R.R. \& Nourshargh, S. A monoclonal antibody recognizing very late antigen-4 inhibits eosinophil accumulation in vivo. J Exp Med 1993, 177: $561-566$

60. Kyan-Aung, U., Haskard, D.O., Poston, R.N., Thornhill, M.H. \& Lee, T.H. Endothelial leukocyte adhesion molecule1 and intercellular adhesion molecule- 1 mediate adhesion of eosinophils to endothelial cells in vitro and are expressed by endothelium in allergic cutaneous inflammation in vivo. $J$. Immunol 1991, 146, 521-528.

61. Bentley, A.M., Robinson, D.S., Menz, G. et al. Expression of the endothelial and leukocyte adhesion molecules ICAM$1, \mathrm{E}-$ selectin and VCAM- 1 in the bronchial mucosa in steady state and allergen induced asthma. J Allergy Clin Immunol 1992, 90, 857-868.

62. Dri, P., Cramer, R., Spessotto, R., Romano, M.\& Patriarca, P. Eosinophil activation on biological surfaces. Production of $\mathrm{O}_{2}$ in response to physiologic soluble stimuli is differentially modulated by extracellular matrix components and endothelial cells. $J$ Immunol 1991, 147: 613-620.

63. Anwar, A.R.E., Walsh, G.M., Cromwell, O., Kay, A.B. \& Wardlaw, A.J. Adhesion to fibronectin primes eosinophils via $\alpha 4 \beta 1$ (VLA-4). Immunology 1994 82: 222-228.

64. Anwar, A.R.E., Moqbel, R., Walsh, G.M., Kay, A.B. \& Wardlaw, A.J. Adhesion to fibronectin prolongs eosinophil survival. J Exp Med 1993, 177: 839-843.

65. Capron, M., Capron, A., Dessaint, J.-P. et al. Fc receptors for IgE on human and rat eosinophils. J Immunol 1981, 126: 2087-2092.

66. Capron, M., Joualt, T., Prin, L. et al. Functional study of a monoclonal antibody to IgE Fc receptor (Fc R2) of eosinophils, platelets and macrophages. J Exp Med 1986, 164: 72-89.

67. Capron, M., Troung, M.-J., Desreumaux, P., Lamkhioued, B., Tomassini, M. \& Capron, A. Eosinophil membrane receptors: function of IgE and IgA binding molecules: in Eosinophils. Immunological and clinical aspects. Gleich, G.J. \& Kay, A.B. (eds) Marcel Dekker, New York, 1994. Chapter 11, pp. 225-238.

68. Unkeless, J.C., Scigliano, E. \& Freedman, V.H. Structure and function of human and murine receptors for IgG. Annu Rev Immunol 1988, 6: 251 .

69. Hartnell, A., Kay, A.B. \& Wardlaw, A.J. IFN- $\gamma$ induces expression of FcgRIII(CD16) on human eosinophils. $J$ Immunol 1992, 148: 1471-1478.

70. Abu-Ghazaleh, R.I., Fujisawa, T., Mestecky, J., Kyle, R.A. \& Gleich, G.J. IgA-induced eosinophil degranulation. J Immunol 1989, 142: 2393-2400.

71. Weller, P.F., Rand, T.H., Barrett, T., Elovic, A., Wong, D.T. \& Finberg, R.W. Accessory cell function of human eosinophils. HLA-DR-dependent, MHC-restricted antigenpresentation and IL-1 alpha expression. J Immunol 1993, 150: 2554

72. Nishikawa, K., Morii, T., Ako, H., Hamada, K., Saito, S. \& Narita, N. In vivo expression of CD69 on lung eosinophils in eosinophilic pneumonia: CD69 as a possible activation marker for eosinophils. J Allergy Clin Immunol 1992, 90: 169-174.
73. Kameyoshi, Y., Dorschner, A., Mallet, A.I., Christophers, E. \& Schroder, J.-M. Cytokine RANTES released by thrombin stimulated platelets is a potent attractant for human eosinophils. J Exp Med 1992, 176: 587-592.

74. Wardlaw, A.J., Moqbel, R., Cromwell, O. \& Kay, A.B. Platelet activating factor. A potent chemotactic and chemokinetic factor for human eosinophils. $J$ Clin Invest 1986, 78: $1701-1706$

75. Sehmi, R., Cromwell, O., Taylor, G.W. \& Kay, A.B. The identification of guinea pig eosinophil chemotactic factor of anaphylaxis (ECF-A) as leukotriene B4 and 8(S)15(S)diHete. J. Immunol 1991, 147: 2276-2283.

76. Warringa, R.J., Koenderman, L., Kok, P.T.M., Kreukniet, J. \& Bruijnzeel, P.L.B. Modulation and induction of eosinophil chemotaxis by granulocyte-macrophage colony stimulating factor and interleukin 3. Blood 1992, 77: 2694-2700.

77. Sehmi, R., Wardlaw, A.J., Cromwell, O., Kurihara, K., Waltman, P. \& Kay, A.B. Interleukin-5 (IL-5) selectively enhances the chemotactic response of eosinophils obtained from normal, but not eosinophilic subjects. Blood 1992, 79: 2952-2959.

78. Henocq, E. \& Vaargaftig, B.B. Accumulation of eosinophils in response to intracutaneous PAF-acether and allergens in man. Lancet 1986, 1: 1378.

79. Wardlaw, A.J., Chung, K.F., Moqbel, R. et al. Effects of iv inhaled PAF in human on circulating and bronchoalveolar o lavage fluid neutrophils. Am Rev Respir Dis 1990, 141, 386-392.

80. Laitinen, L.A., Laitinen, A., Haahtela, T., Vikka, V., Spur, B.W. \& Lee, T.H. Leukotriene E4 and granulocytic infiltration into asthmatic airways. Lancet 1993, 341, 989-990.

81. Weller, P.F. Eicosanoids, cytokines and other mediators elaborated by eosinophils. In: Makino, S. \& Fukuda, T (eds) Eosinophils, Biological and Clinical Aspects. CR8 Press, Baco Raton, FL, 1993, pp. 125-154.

82. Weller, P.F., Lee, C.N., Foster, D.W., Corey, E.J., Auste K.F. \& Lewis, R.A. Generation and metabolism of 5 lipoxygenase pathway leukotrienes by human eosinophils; predominant production of leukotriene C4. Proc Natl Acad Sci USA 1983, 80: 7625-7630.

83. Barker, R.L., Gleich, G.J. \& Pease, L.R. Acidic precursor revealed in human eosinophil granule major basic protein cDNA. $J$ Exp Med 1988, 168: 1493-1498.

84. Butterworth, A.E., Wassom, D.L., Gleich, G.J., Loegering D.A. \& David, J.R. Damage to schistosomula of S. manson induced directly by eosinophil major basic protein. $J$ Immunol 1979, 122: 221-229.

85. Gleich, G.J. The eosinophil and bronchial asthma: curren understanding. J Allergy Clin Immunol 1986, 85: 422-436.

86. Gundel, R.H., Letts, L.G. \& Gleich, G.J. Human eosinophil major basic protein induces airway constriction and airway hyperresponsiveness in primates. J Clin Invest 1991, 87: 1470-1473.

87. Rohrbach, M.S., Wheatley, C.L., Slifman, N.R. \& Gleich, G.J. Activation of platelets by eosinophil granule proteins. $J$ Exp Med 1990, 172: 1271-1274.

88. Ten, R.M., Pease, L.R., McKean, D.J., Bell, M.P. \& Gleich, G.J. Molecular cloning of the human eosinophil peroxidase J Exp Med 1989, 169: 1757-1769.

89. Rosenburg, H.F., Ackerman, S.J. \& Tenen, D.G. Human N eosinophil cationic protein. Molecular cloning of a cytotoxin and helminthotoxin with ribonuclease activity. $J$ Exp Med 1989, 170: 163-176.

90. Tai, P.C., Spry, C.J.F., Peterson, C., Venge, P. \& Olsson, I Monoclonal antibodies distinguish between storage and secreted forms of eosinophil cationic protein. Nature 1984, 309: $182-184$.

91. Rosenburg, H.F., Tenen, D.G. \& Ackerman, S.J. Molecular cloning of the human eosinophil-derived neurotoxin: a member of the ribonuclease gene family. Proc Natl Acad Sci USA 1989, 86: 4460-4964. 
92. Weller, P.F., Goetzl, E.J. \& Austen, K.F. Identification of human eosinophil lysophospholipase as the constituent of Charcot-Leyden crystals. Proc Natl Acad Sci USA 1980, 77: 7440-7443.

93. Wong, D.T., Weller, P.F., Galli, S.J. et al. Human eosinophils express transforming growth factor $\alpha$. J Exp Med 1990, 172: 673-681.

94. Leary, A.G. \& Ogawa, M. Identification of pure and mixed basophil colonies in culture of human peripheral blood and marrow cells. Blood 1984, 64: 78-83.

95. Moqbel, R., Hamid, Q. \& Sun Ying. Expression of mRNA and immunoreactivity for the granulocyte/macrophagecolony stimulating factor (GM-CSF) in activated human eosinophils. J Exp Med 1991, 174: 749-752.

96. Braun, R.K., Franchini, M., Erard, F. et al. Human peripheral blood eosinophils produce and release interleukin-8 on stimulation with calcium ionophore. Eur J Immunol 1993, 23: 956-960.

97. Broide, D.H., Paine, M.M. \& Firestein, G.S. Eosinophils express interleukin 5 and granulocyte macrophage colonystimulating factor $\mathrm{mRNA}$ at sites of allergic inflammation in asthmatics. J Clin Invest 1992, 90: 1414-1424.

98. Wong, D.T.W., Elovic, A. \& Matossian, K. Eosinophils from patients with blood eosinophilia express transforming growth factor $\beta 1$. Blood 1991, 78: 2702-2707.

99. Hamid, Q., Barkans, J., Meng, Q., Ying, S., Abrams, J.S., Kay, A.B. \& Moqbel, R. Human eosinophils synthesize and secrete interleukin-6, in vitro. Blood 1992, 80: 1496-1501.

100. Spry, C. Eosinophils. Oxford University Press, Oxford, London, 1988, p. 29.

101. Yazdanbakhsh, M., Eckmann, C.M. \& Roos, D. Characterization of the interaction of human eosinophils and neutrophils with opsonized particles. J Immunol 1985, 135: 1378-1384.

102. Kroegel, C., Yukawa, T., Dent, G., Venge, P., Ghung, F.K. \& Barnes, P.J. Stimulation of degranulation from human eosinophils by platelet activating factor. J Immunol 1989 , 142: 3518-3526.

103. Khaliffe, J., Capron, M., Cesbron, J.Y. et al. Role of specific IgE antibodies in peroxidase (EPO) release from human eosinophils. J Immunol 1986, 137: 1659-1664.

104. Nusse, O., Lindau, M., Cromwell, O., Kay, A.B. \& Gomperts, B.D. Intracellular application of guanosine-5' O-(3-thiotriphosphate) induces exocytic granule fusion in guinea pig eosinophils. J Exp Med 1990, 171: 775-786.

105. Giembycz, M.A. \& Barnes, P.J. Stimulus-response coupling in eosinophils: receptors, signal transduction and pharmacological modulation. In: Smith, H. \& Cook, R.M. (eds) Immunopharmacology of Eosinophils. Academic Press, London, 1993, pp. 91-118.

106. Lopez, A.F., Sanderson, C.J., Gamble, J.R., Cambell, H.D., Young, I.G. \& Vadas, M.A. Recombinant human interleukin 5 is a selective activator of human eosinophil function. J Exp Med 1988, 167: 219-224.

107. Slungard, A., Vercellotti, G.M., Walker, G., Nelson, R.D. \& Jacob, H.S. Tumor necrosis factor $\alpha /$ cachectin stimulates eosinophil oxidant production and toxicity towards human endothelium. J Exp Med 1990, 171: 2025.

108. Yamaguchi, Y., Suda, T., Ohta, S. et al. Analysis of the survival of mature human eosinophils: interleukin-5. Blood 1991, 78: 2542-2547.

109. Krause, J.R. \& Boggs, D.R. Search for eosinophilia in hospitalized patients with normal blood leukocyte concentration. Am J Haematol 1987, 24: 55-63.

110. Matheson, A., Rosenblum, A., Glazer, R. \& Dacanay, E. Local tissue and blood eosinophils in newborn infants. $J$ Pediatr 1957, 51: 502

111. Winkel, P., Statland, B.E., Saunders, A.M., Osborn, H. \& Kupperman, H. Within day physiologic variation of leukocyte types in healthy subjects as assayed by two automated leukocyte differential analyzers. $\mathrm{Am} J \mathrm{Clin}$ Pathol 1981, 75: 693-700.
112. Weller, P.F. \& Goetzl, E.J. The regulatory and effector roles of eosinophils. Adv Immunol 1979, 27: 339-371.

113. Gleich, G.J. The eosinophil and bronchial asthma: current understanding. J Allergy Clin Immunol 1990, 85: 422-436.

114. Todd, R., Donoff, B.R. \& Chiang, T. The eosinophil as a cellular source of transforming growth factor alpha in healing cutaneous wounds. Am J Pathol 1991, 138: 1307.

115. Lowe, D., Jorizzo, J. \& Hutt, M.S.R. Tumour associated eosinophilia, a review. J Clin Path 1981, 34: 1343-1348.

116. Spry, C.J.F. The idiopathic hypereosinophilic syndrome. In: Makino, S. \& Fukuda, T. (eds) Eosinophils: Biological and Clinical Aspects. CRC Press, Boca Raton, FL, 1993, pp. 403-420.

117. Butterworth, A.E. Cell mediated damage to helminths. Adv Parasitology 1984, 23: 143-235.

118. Filley, W.V., Holley, K.E., Kephart, G.M. \& Gleich, G.J. Identification by immunofluorescence of eosinophil under granule major basic protein in lung tissue of patients with bronchial asthma. Lancet 1982, 2: 11-16.

119. De Monchy, J.G.R., Kauffman, H.F., Venge, P. et al. Bronchoalveolar eosinophilia during allergen-induced late asthmatic reactions. Am Rev Respir Dis 1985, 131: 373-376.

120. Lam, S., LeRichie, J., Phillips, D. et al. Cellular and protein changes in bronchial lavage fluid after late asthmatic reaction in patients with red cedar wood asthma. $J$ Allergy Clin Immunol 1987, 80: 44-50.

121. Fabbri, L.M., Boschetto, P. \& Zocca, E. Bronchoalveolar neutrophilia during late asthmatic reactions induced by toluene diisocyanate. Am Rev Respir Dis 1987, 136: 36-42.

122. Metzger, W.J., Zavala, D., Richerson, H.B. et al. Local allergen challenge and bronchoalveolar lavage of allergic asthmatic lungs: description of the model and local airway inflammation. Am Rev Respir Dis 1987, 135: 433-440.

123. Frew, A.J. \& Kay, A.B. The relationship between infiltrating CD4 + lymphocytes, activated eosinophils and the magnitude of the allergen induced late-phase response in man. $J$ Immunol 1988, 141: 4158-4165.

124. Bentley, A.M., Jacobson, M.R. Cumberworth, V. et al. Immunohistology of the nasal mucosa in seasonal allergic rhinitis: increase in activated eosinophils and epithelial mast cells. J Allergy Clin Immunol 1992, 89: 877.

125. Godard, P., Chaintreuil, J., Damon, M. et al. Functional assessment of alveolar macrophages comparison of cells from asthmatics and normal subjects. J Allergy Clin Immunol 1982, 70: 88-93.

126. Flint, K.C., Leung, K.B., Hudspith, B.N., Brostoff, J., Pearce, F.L. \& Johnson, N.M. Bronchoalveolar mast cells in extrinsic asthma: a mechanism for the initiation of antigen specific bronchoconstriction. Br Med J 1985, 291: 923-926.

127. Tomioka, M., Ida, S., Shindoh, Y., Ishihara, T. \& Takashima, T. Mast cells in bronchoalveolar lumen of patients with bronchial asthma. Am Rev Respir Dis 1984, 129: $1000-1005$

128. Wardlaw, A.J., Dunnette, S., Gleich, G.J., Collins, J.V. \& Kay, A.B. Eosinophils and mast cells in bronchoalveolar lavage fluid and mild asthma: relationship to bronchial hyperreactivity. Am Rev Respir Dis 1988, 137: 62-69.

129. Azzawi, M., Bradley, B., Jeffery, P.K. et al. Identification of activated $\mathrm{T}$ lymphocytes and eosinophils in bronchial biopsies in stable atopic asthma. Am Rev Respir Dis 1990, 142: $1407-1413$.

130. Hartnell, A., Robinson, D.S., Kay, A.B. \& Wardlaw, A.J. CD69 is expressed by human eosinophils activated in vivo in asthma and in vitro by cytokines. Immunology 1993, 80: 281-286.

131. Robinson, D.S., Hamid, Q. \& Sun Ying. Evidence for a predominant Th2-type bronchoalveolar lavage $\mathrm{T}$ lymphocyte population in atopic asthma. N Engl J Med 1992, 326: $298-304$. 
132. Jeffery, P.K., Wardlaw, A.J., Nelson, F.C., Collins, J.V. \& Kay, A.B. Bronchial biopsies in asthma: an ultrastructural, quantitative study and correlation with hyperreactivity. $\mathrm{Am}$ Rev Respir Dis 1990, 140: 1745-1753.

133. Bentley, A.M., Maestrelli, P., Saetta, M. et al. Activated T lymphocytes and eosinophils in the bronchial mucosa in isocyanate-induced asthma. J Allergy Clin Immunol 1992 , 89: 821-829.

134. Bentley, A.M., Menz, G., Storz, C.H.R. et al. Identification of $\mathrm{T}$ lymphocytes, macrophages and activated eosinophils in the bronchial mucosa in intrinsic asthma: relationship to symptoms and bronchial responsiveness. Am Rev Respir Dis 1992, 146: 500-506.

135. Allen, J.N., Davis, W.B. \& Pacht, E.R. Diagnostic significance of increased bronchoalveolar lavage fluid eosinophils. Am Rev Respir Dis 1990, 142: 642-647.

136. Bousquet, J., Chanez, P., Lacoste, J.Y. et al. Eosinophilic inflammation in asthma. N Engl J Med 1990, 323: 1033-1039.

137. Diaz, P., Galleguillos, F.R., Gonzales, M.C., Pantin, C.F. \& Kay, A.B. Bronchoalveolar lavage in asthma: the effect of disodium cromoglycate (cromolyn) and leukocyte counts, immunoglobulins and complement. J Allergy Clin Immunol 1984, 74: 41-48.

138. Schleimer, R.P. Effects of glucorticosteroids on inflammatory cells relevant to their therapeutic applications in asthma. Am Rev Respir Dis 1990, 141: S59-S69.

139. Juniper, E.F., Kline, P.A., Vanzieleghem, A., Ramsdale, H., O'Byrne, P.M. \& Hargreave, F.E. Effect of long term treatment with an inhaled corticosteroid (budesonide) on airway hyperresponsiveness and clinical asthma in non steroid dependent asthmatics. Am Rev Respir Dis 1990, 142: 832.

140. Wegner, C.D. Gundel, R.H., Reilly, P., Haynes, N., Letts, G.L. \& Rothlein, R. Intercellular adhesion molecule-1 (ICAM-1) in the pathogenesis of asthma. Science 1990, 247: 456-459.

141. Taylor, I.K. \& Shaw, R.J. The mechanism of action of corticosteroids in asthma. Resp Med 1993, 87: 261.

142. Gibson, P.G., Manning, P.J. \& O'Byrne, P.M. Chronic cough; eosinophilic bronchitis without asthma. Lancet 1989, 1: 1346.

143. Adelroth, E., Rosenhall, L., Johansson, S., Linden, M. \& Venge, P. Inflammatory cells and eosinophilic activity in asthma investigated by bronchoalveolar lavage. The effects of anti-asthmatic treatment with budesonide or terbutaline. Am Rev Respir Dis 1990, 142: 91-99.

144. Kojima, S. Eosinophils in parasitic diseases. In: Makino, S. \& Fukuda, T. (eds) Eosinophils, Biological and Clinical Aspects. CRC Press, Boca Raton, FL, 1993, pp. 391-402.
145. Spry, C.J.F. Eosinophils. Oxford University Press, Oxford, 1988, p.136

146. Butterworth, A.E. \& Thorne, K.J.I. Eosinophils and parasitic diseases. In: Smith, H. \& Cook, R.M. (eds) @ Immunopharmacology of Eosinophils. Academic Press, $C$ London, 1993, pp. 119-150.

147. Gleich, G.J. \& Adolphson, C.R. The eosinophil leukocyte: structure and function. Adv Immunol 1986, 39: 177-253.

148. Kephart, G.M., Gleich, G.J., Connor, D.H., Gibson, D.W. \& Ackerman, S.J. Deposition of eosinophil granule major basic protein onto micofilariae of Onchocerca volvulus in the skin of patients treated with diethylcarbamazine. $L a b$ Invest 1984, 50: 51-61.

149. Hagan, P., Wilkins, H.A., Blumenthal, U.J. et al. @ै Eosinophilia and resistance to Schistosoma haematobium in man. Parasite Immunol 1985, 7: 625-632.

150. Sher, A., Coffman, R.L., Hieny, S. \& Cheever, A.W. Ablation of eosinophil and IgE responses with anti-IL-5 and $\vec{\omega}$ anti-IL-4 antibodies fails to affect immunity against Schistosoma mansoni larvae in the mouse. J. Immunol 1990, 145: 3911-3916.

151. Guillevin, L., Guittard, T., Bletry, O., Godeau, P. \& Rosenthal, P. Systemic necrotizing angiitis with asthma: causes and precipitating factors in 43 cases. Lung 1987, 165: 165-172.

152. Belongia, E.A., Mayeno, A.N., Gleich, G.J. \& Kita, H. oj Eosinophilia-myalgia syndrome. In: Makino, S. \& Fukuda, o T. (ed.) Eosinophils, Biological and Clinical Aspects. CRC 음 Press, Boca Raton, FL, 1993, pp. 421-440.

153. Beeson, P.B. \& Bass, D.A. Mechanisms of eosinopenia. In: Beeson, P.B. \& Bass, D.A. (eds) The Eosinophil. W.B. Saunders, Philadelphia, 1977, p. 92.

154. Juhlin, L. \& Michaelsson, G. A new syndrome characterized by absence of eosinophils and basophils. Lancet 1977, $1233-1235$.

155. Telerman, A., Amson, R.B. Delforge, A. et al. A case chronic aneosinocytosis. Am J Hematol 1982, 12: 187-19z

156. Nakahata, T., Spicer, S.S., Leary, A.G., Ogawa, MFranklin, W. \& Goetzl, E.J. Circulating eosinophil colonyforming cells in pure eosinophil aplasia. Ann Intern Med 1984, 101: 321-324.

157. Joshua, H., Zucker, A. \& Presentey, B. Peroxidase and phospholipid deficiency in eosinophilic granulocytes among Arabs of the Nazareth district. Isr J Med Sci 1976, 12: 71-73. 